\title{
Rational design of protein kinase inhibitors
}

\author{
S. M. Yarmoluk, A. Yu. Nyporko, V. G. Bdzhola \\ Institute of Molecular Biology and Genetics, NAS of Ukraine \\ 150, Akademika Zabolotnogo Str., Kyiv, Ukraine 03680 \\ sergiy@yarmoluk.org.ua
}

\begin{abstract}
Modern methodological approaches to rational design of low molecular weight compounds with specific activity in relation to predetermined biomolecular targets are considered by example of development of high effective protein kinase inhibitors. The application of new computational methods that allow to significantly improve the quality of computational experiments (in, particular, accuracy of low molecular weight compounds activity prediction) without increase of computational and time costs are highlighted. The effectiveness of strategy of rational design is demonstrated by examples of several own investigations devoted to development of new inhibitors that are high effective and selective towards protein kinases CK2, FGFR1 and ASK1.
\end{abstract}

Keywords: rational desing, protein kinase inhibitors, low molecular weight compounds, protein kinases CK2, FGFR1 and ASK1.

Introduction. Kinases are almost widest family of human enzymes - about $1.7 \%$ of all proteins, encoded in human genome, are protein kinases [1], which in couple with their antagonists protein phosphatases regulate numerous metabolic processes in eukaryotic cell via control of protein phosphorylation level. The transfer of the phosphate group to the amino acid residue of the substrate protein is one of key stages in the start and transmission of intracellular signaling, responsible for cell cycle progress, cell differentiation, intercellular and cell-substrate interactions, cell motility, immune response, channel and transporter activity, processes of transcription, translation and main metabolism. The majority of protein kinases contain at least one residue of hydroxy amino acid, the phosphorylation of which causes conformational changes and, as consequence, the transition of protein kinase into active form [2-4]. Constitutively active kinases are an exception.

Total involvement of protein kinases into metabolic processes has its downside - a lot of protein kinases are key factors of genesis of various dangerous diseases.

(C) Institute of Molecular Biology and Genetics, NAS of Ukraine, 2013
Among kinase-dependent pathologies one should mention diabetes, inflammatory processes of various etiology, cardiovascular diseases, pathogenesis of several infectious diseases as well as numerous of oncological diseases [5-6].

Taking into consideration the crucial role of protein kinases in the regulation of proteome status, their study should be conducted using a specific set of molecular instruments of sophisticated control of the activity of individual protein kinases. These molecular instruments may be protein kinase inhibitors characterized by a high degree of selectivity. The availability of these inhibitors would allow to «switch off» certain protein kinases and observe metabolic consequences of such targeted effect, which would expand the current views on both kinome functions and metabolome in general. At the same time these inhibitors could be used as a basis for the development of high efficient drugs for treatment of oncological and other human diseases.

It's completely logical that the development of effective and selective protein kinases inhibitors and newest drugs on their base is one of vital tasks of modern pharmacology [7-9]. Bibliographic database of National Cen- 
ter for Biotechnological Information of USA PubMed contains about 5000 references to works relating to design of compounds capable to inhibit protein kinases. However, one should mention that at the end of last year the only sixteen or so compounds were approved as drugs despite numerous researches in this field [10].

Strategy of rational design of protein kinase inhibitors. A conventional strategy of rational design of protein kinase inhibitors is based on the fine understanding of structural mechanisms of specific binding of low molecular weight organic compounds with these enzymes. According to the mechanism of interaction, the protein kinase inhibitors are divided into three groups $[9,11]$. The first and probably the widest group consists of the compounds that are able to directly interact with ATP binding site of protein kinases (type I inhibitors). They contain classical donors and acceptors of hydrogen bond and form at least one such bond with a hinge region of the site, which in norm is the place of adenine binding. While interacting with type I inhibitors, kinases are in activated (phosphorylated) state. Type I inhibitors are various chemical analogues of nucleobases. It is natural that type I inhibitors are generally characterized by a low level of selectivity. However, several selective representatives of these compounds are not only are discovered but approved for clinical use, in particular, fasudil, gefitinib (iressa), erlotinib, sunitinib and dasatinib.

Contrary to type I inhibitors, type II inhibitors interact with the so called extended ATP binding site of inactivated protein kinase. Besides the sites of binding adenine, ribose and phosphate, which are very conservative for all protein kinases, this site also contains an additional hydrophobic pocket that opens due to conformational changes during the transition of protein kinase from the active state into the inactive one. This pocket is less conservative for its amino acid content, and type II inhibitors a priori demonstrate higher selectivity compared to type I inhibitors. Type II inhibitors are approved for clinical use, include such compounds as imatinib (well-known by its trade name, glivec), sorafenib (nexavar), lapatinib, nilotinib $[9,10]$.

Type III inhibitors are completely allosteric; they have individual sites of interaction and, contrary to two previous types, do not compete with ATP $[9,10]$. The- se compounds demonstrate the highest degree of selectivity, however, the number of known type III inhibitors is few and none of them approved as a medicine. The search or design of new inhibitors interacting with allosteric sites could be promising due to their high selectivity but the lack of information about allosteric sites on the surface of many protein kinases extremely limits the possibilities of the rational design of these compounds.

Taking the above mentioned into consideration, it is reasonable that the rational design of selective inhibitors of kinases as rule is based on the development of compounds able to specifically interact with ATP binding sites, i. e. type I and II inhibitors, introducing corresponding substituents interacting with «surrounding» (allosteric) sites.

The strategy of the rational design is concerted combination of computational approaches used for detailed analysis of structural mechanisms of inhibitors interaction with molecules of protein kinases and their affinity predicted with instrumental methods of estimation of activity and selectivity of the developed compounds. The procedure of the rational design consists of the following stages:

- target selection;

- analysis of individual specificities of the spatial structure of ATP-binding and allosteric sites of target protein kinases;

- high-throughput receptor-based virtual screening of the database of low molecular weight organic compounds and determination of classes of compounds with the highest in silico affinity to target protein kinases;

- experimental verification of the inhibitor activity and selectivity of the most promising compounds accordantly to data of the previous stage on set of target protein kinases in vitro;

- correlative analysis of structure activity relationship (SAR) using the results of biochemical assays and determination of hit compounds for subsequent chemical optimization;

- synthesis and chemical optimization of new inhibitors based on SAR analysis, selectivity and computational modelling data.

New computational approaches. In silico methods are good productive for search of low molecular weight compounds with predetermined specific activity in rela- 
tion to specified biomolecular targets. They allow to rationally restrict range of compounds for the next wet experiments and, thus, to reduce the time and cost for the development of new biologically active compounds with targeted effect and new drugs in particular. However, when researchers apply them for the tasks of highthroughput virtual screening (HTVS), they have to use simplified estimating methods that downshift the affinity and/or activity prediction.

Yakovenko et al. [12-14] developed and introduced a number of new computational methods allowing to essentially improve the quality of computational experiments without any increase in estimation capacity and time.

Due to large size of biomolecular systems the highly efficient quantum methods of simulating intermolecular interactions in HTVS are rarely used. The force field method, based on Coulomb interaction, is used instead since it provides simple calculation and requires only the data on the electric charge distribution on atoms of the analysed compounds. Based on the principle of electronegativity relaxation of the Kirchhoff charge model, an original method is developed to determine the distribution of the electric charge [13], which presents the electric density distribution as a discrete set of point charges localized on atoms. Similar approach previously described in [15] contains several disadvantages resulting in method constant bias and the reduction of its performance.

The authors not only improved the formalism of the electronegativity relaxation method but also performed its parameterization by quantum approaches at the $\mathrm{HF} /$ 6-311++G(d, p) level of theory. On average the deviation in reproducing the experimental values of dipole and quadruple moments of organic molecules using the developed method does not exceed $0.3 \mathrm{D}$ and $0.2 \mathrm{~B}$, respectively [13]. The developed method is universal and differs from well-known empirical methods by its performance and high accuracy of reproducing of the charge distribution on the atoms of organic molecules.

The same authors designed a new force field (FF) YFF1 for further estimation of intermolecular interactions in HTVS [14] which combines the authors' scheme of atomic charges calculation [13] and basic parameterization of covalent and van der Waals interactions of the force field MMFF94, specifically parameterized for the reproduction of interactions in the «biopolymer-ligand» systems [16].

FF YFF1 enhances the accuracy of computation of electrostatic interactions, declared in FF MMFF94, by at least an order (average deviation of reproducing electric moments is $0.8-1.2 \mathrm{D}$ ) and is the best among other FF to estimate the energy of intermolecular interactions in the «protein-ligand» systems. A software complex, ensuring automatic compilation of free organic structure in FF YFF1, is designed [14].

The ligand solvatation energy should be taken into account for the accurate estimation of ligand affinity to the receptor. To use in the HTVS tasks, the same authors modified the formalism of computation of solvatation energies of ligands compared to GBSA model $[17,18]$ by increasing the response rate of the algorithm via the introduction of effective Born radius estimation [19]. The modified GBSA model was tested on a set of $>400$ compounds of various classes with experimentally defined values of desolvatation energy. The obtained value of linear correlation coefficient between predicted and experimentally defined values is 0.84 which is currently the highest for known empirical methods of GBSA family [20].

Yakovenko et al. used the formalism of function of the states distribution of molecular assembly by the degree of freedom for the estimation of molecular affinity with the consideration of entropy effects. A unique method was designed to assess the functions of distribution for both rotational and translational as well as for internal degrees of freedom for molecular complexes. As the accuracy criterion for the prognosis of intermolecular affinities was chosen the anticipation of experimentally defined inhibition constants $\left(K_{i}\right)$ for the enzyme inhibitors, since this parameter does not depend on the conditions of its determination, on the substrate concentration in particular [20].

The developed models and algorithms were used in the department of medicinal chemistry to create the laboratory program complex for HTVS of low molecular organic compounds. This is the first Ukrainian program complex that is applied for drug search and development.

The application of developed novel computational approaches to the procedure of rational design provided the successful development of new efficient inhibitors 
of several protein kinases, in particular CK2, FGFR1 and ASK1.

Inhibitors of protein kinase CK2. An extremely attractive target for the search of inhibitors among the representatives of serine-threonine protein kinases is a highly conservative CK2 (casein kinase 2), presented in all the eukaryotic organisms [21-24]. CK2 has over 400 physiological targets (factors of growth and transcription, regulators of cellular cycle and apoptosis, components of response to stress, etc.) [25-28], while its overexpression results in the development of a number of pathologies, including oncological diseases [29-34], Alzheimer's disease [35], glomerulonephritis [36], inflammatory processes [37], a number of viral infections [27], diabetes-associated eye diseases [38]. Therefore, selective inhibitors of CK2 may be important key for study of cell signaling pathways as well as successfully use in medical practice.

High-throughput virtual screening of the database of compounds of department of medicinal chemistry of IMBG NASU, biochemical testing in vitro and subsequent chemical optimization allowed to develop new selective inhibitors of CK2. Despite the numerous works in the search of CK2 inhibitors, namely the scientific team of the IMBG medicinal chemistry department has the first officially registered patents for inhibitors of this protein kinase - UA68984 and UA69165 [39]. The inhibitory activity of such classes of compounds as 3 carboxy-4- $(1 H)$-quinolones $[40,41]$ and tetrahalogeno1,3-dioxo-2,3-dihydroisoindoles [42,43] was demonstrated for the first time.

These compounds interact with CK2 via a common mechanism, forming hydrogen bonds with aminoacid residues Lys 68, Asp175, Glu81, Trp176 and forming hydrophobic contacts with residues Phe113, Val66, Val53, Ile174.

Among the derivatives of 3 carboxy-4-( $1 H)$-quinolones, the highest inhibitory activity was registered for compounds 3.7 (5,6,8-trichloro-4-oxo-1,4-dihydroquinoline-3-carboxylic acid) and 3.55 (7,8-dichloro-4oxo-1,4-dihydroquinoline-3-carboxylic acid), characterized by nanomolar values of $K_{i}(60$ and $150 \mathrm{nM})$ and $\mathrm{IC}_{50}$ (300 and $800 \mathrm{nM}$, respectively) [40, 41]. For compound 3.7, high level of selectivity was also determined. On the testing panel consisting of 7 kinases only in case of protein kinase DYRK1a the some inhibition was revealed, but this is typical for other selective inhibitors of CK2 kinase [44].

The tetrahalogeno-1,3-dioxo-2,3-dihydroisoindoles also have a number of compounds capable to inhibit CK2 in nanomolar concentrations. Among the representatives of this class the most active one is TID46 2(4,5,6,7-iodo-1,3-dioxo-2,3-dihydro-1 $H$-2-isoindolyl) propanoic acid with $\mathrm{IC}_{50} 150 \mathrm{nM}$ and the inhibition constant value of $100 \mathrm{nM}$. The results of testing selectivity of inhibitors affecting protein kinases DYRK1a, MSK1, GSK3 and CDK5 demonstrated that in the concentration of $10 \mu \mathrm{M}$ this compound causes insignificant inhibition of these kinases [42, 43].

The ability to inhibit CK2 was also revealed for derivatives of 4-aminoquinazoline and 4-amino-3-carbetoxyquinoline $[45,46]$. It was previously demonstrated that tyrphostin AG1478 (4-(3-chloroanilino)-6,7dimethoxyquinazoline) is able to inhibit CK2 activity [47]. Among the representatives of these classes there were no compound, capable to inhibit CK2 in nanomolar concentrations, but the optimization of inhibitors, for instance, via glycosylation in certain positions, allowed decreasing $\mathrm{IC}_{50}$ from 7.7 to $3 \mu \mathrm{M}$ for 4-aminoquinazolines and from 9 to $2 \mu \mathrm{M}$ for 4 -amino-3-carbetoxyquinolines.

The several compounds with high CK2-inhibiting activity were obtained via optimization of derivatives of flavones on the basis of developed models of their interaction with the kinase. For instance, 26 out of 28 synthesized de novo derivatives of 4'-hydroxyflavone $(92.8 \%)$ were characterized by nanomolar activity values. The most efficient among them were compounds FNH68 (6,8-dichloro-2-(4-hydroxy-3-methoxyphenyl)chromen-4-on) $-\mathrm{IC}_{50}=10 \mathrm{nM}, K_{i}==3.6 \mathrm{nM}-$ and FNH79 (6,8-dibromo-2-(4-hydroxy-3-methoxyphenyl)chromen-4-on) $-\mathrm{IC}_{50}=4 \mathrm{nM}, K_{i}=1.8 \mathrm{nM}$, also characterized by high levels of selectivity on the panel of testing protein kinases.

Among other types of flavone derivatives, the essential CK2-inhibiting activity is shown for some representatives of 4'-carboxyflavonols [48]. The optimization of 3-hydroxy-2-phenyl-chromen-4-on by the introduction of substituents into positions 6 and 8 allowed to obtain the panel of 13 new derivatives. They all had submicromolar (nanomolar) values of $\mathrm{IC}_{50}$. The most active compounds are FLC21 4-(6,8-dichloro-3-hydro- 
xy-4-oxo-4H-chromen-2-yl)benzoic acid and FLC26 4-(6,8-dibromo-3-hydroxy-4-oxo-4H-chromen-2-yl) benzoic acid $\left(\mathrm{IC}_{50}-40\right.$ and $9 \mathrm{nM}, K_{i}-13$ and $2.5 \mathrm{nM}$, respectively). In addition, FLC26 demonstrated high selectivity level regarding CK2 compared to other tested kinases (ASK1, Jnk 3, FGFR1, Met, Aurora A, Tie 2 and Rock 1) [48].

All active flavone inhibitors have a similar type of binding. In all obtained «CK2-inhibitor» complexes the hydrophobic contacts were formed between the ligand and seven aminoacid residues (Leu45, Val53, Val66, Ile 95, Phe113, Met163 and Ile174). The interaction of the phenol ring in position 2 of heterocycle with Phe 113 , Ile95 and Ile 174 is especially important. The contact with Phe113 is realized via stacking interaction, which is of great importance for the fixation of the inhibitor in ATP-binding site. Other key interactions are two intermolecular hydrogen bonds, involving the hinge region (Val116) and pocket (Lys68) that is located deep in the CK2 binding site. The formation of hydrogen bonds in the hinge region is typical for the majority of protein kinase inhibitors, which was confirmed by numerous data of X-ray structural analysis [9]. All this testifies about complementarity of flavones to ATP-binding site of CK2 and their availability for chemical optimization, which was demonstrated in the investigations [48].

The inhibitors of protein kinase CK2 were first found among the derivatives of thieno[2,3-d]pyrimidine [49]. Thienopyrimidines are known as inhibitors of ErbB, PDGF, VEGFR-2, FLT3 and Tie2 kinases [50-52], but there were no data on their CK2-inhibiting activity. The highest activity was demonstrated by compound TTP22 3-(5-p-tolyl-thieno[2,3-d]pyrimidine-4yl-sulfanyl)-propionic acid: its $\mathrm{IC}_{50}$ is $0.1 \mu \mathrm{M}$, while $K_{i}$ is $40 \mathrm{nM}$. This compound is also characterized by fine selectivity on the panel of four serine/threonine (ASK1, JNK3, Aurora A and Rock 1) and three tyrosine protein kinases (FGFR1, Met and Tie2), except for the ability of inhibiting the activity of kinase Aurora A (residual activity $23 \%$ at the concentration of $10 \mu \mathrm{M}$ ).

The key contacts promoting the binding of thieno [2,3-d]pyrimidine inhibitors by CK2 molecule are van der Waals interactions, occurring between the ligand and a number of hydrophobic residues (Leu45, Val53, Val66, Val116 and Ile174). In addition, the compounds form three intermolecular hydrogen bonds in ATP-binding site of CK2. One bond is formed between nitrogen atom in position 1 of thieno[2,3-d]pyrimidine heterocycle and Val116 of the hinge region of CK2. Two other bonds are formed by the substitute R4 (propionic acid) in the hydrophobic region 1 of the active site. The first bond occurs with side chain Lys68, and the second onewith the main chain Asp175.

Inhibitors of protein kinase FGFR1. An attractive target for inhibitor design among the representatives of tyrosine kinases is FGFR1 participating in the formation of mesenchymal tissue, the nervous system, lungs, mammary glands during embryogenesis, and it is involved in reparative processes and tissue homeostasis, inflammation, angiogenesis, differentiation of muscle and fat cells [53]. The overexpression of FGFR1 was registered for several oncological diseases (glioblastoma, breast cancer, prostate cancer, lymphoma, melanoma, etc.) [54].

At present there are only a few known inhibitors of FGFR1 [55], some of which are at the clinical trial stage, but these compounds are active towards the whole family of FGFR protein kinases due to considerable structural similarity of the enzymes, especially in the kinase domain (TKI-258 (Novartis), Brivanib (Bristol Myers Squibb), E7080 (Eisai), AZD4547 (Astra Zeneca)). The most selective class of FGFR1 inhibitors - pyridopyrimidines - did not pass clinical trials because of their high toxicity and is used for research only [55].

The ability to inhibit the activity of FGFR1 was demonstrated by us regarding flavones, oxyindoles and quinasolines. These compounds demonstrate inhibitory properties under condition of heterocycle interaction with the hinge region (the formation of the hydrogen bond) and the presence of the phenol ring linked to the main heterocycle by a flexible spacer and directed towards the hydrophobic pocket 1 FGFR1. The affinity of ligands to FGFR1 is considerably dependended on the nature of substituents in the phenol ring [56-58].

As stated above, the derivatives of flavones are inhibitors of several of protein kinases, in particular, cyclin-dependent kinases [59] and CK2 [48, 60]. Their antitumor and anti-angiogenic activity was revealed in micromolar range of concentrations [61]. According to the results of biological testing, 6 flavone compounds have $\mathrm{IC}_{50}$ under $25 \mu \mathrm{M}$. The ligand with high FGFR1-inhi- 
bitory activity belongs to the structural subclass of flavonols, and the highest effect is demonstrated by the compounds with the substituents in position 3 of the chromen heterocycle, a hydroxyl group, in particular [56].

According to the developed model of interaction of flavonols with FGFR1, phenol radical is oriented inside the binding site. The formation of two hydrogen bonds is possible between the carboxylic and hydroxyl groups of chromen and hinge region of kinase. Chromen heterocycle in this position is surrounded by hydrophobic residues Leu484, Leu630, Phe489 and Ala512. Phenyl radical enters the hydrophobic environment formed by residues Ala640, Ile545 and Lys514, increasing the inhibitor affinity to FGFR1 [56]. The similar orientation of flavonoid inhibitors is observed in the complexes of other kinases - CDK6 and flavopiridol [62], PIM1 and quercetagetin [63], phosphatidyl inositol kinase $\gamma$ and quercetin [64].

The developed model of binding allowed us to assume that hydrophobic groups in position 6 of chromenon enter into energetically beneficial hydrophobic environment of side chains of aminoacid residues Leu484 and Tyr563 in the active site. At the same time the methyl substituent in position 7 does not have any hydrophobic environment in the enzyme pocket. The methyl substituent in position 8 is quite close to the side chain Phe 489 and can change the binding mode of the ligand with kinase. Thus, the introduction of hydrophobic substituents into position 6 of chromen heterocycle increases the affinity of flavonols to the kinase via hydrophobic interactions, while hydrophobic substituents in positions 7 and 8 do not have a similar effect [56].

Oxyindoles have already been known as active inhibitors of tyrosine protein kinases. For instance, sunitinib was introduced into clinical practice in 2006 as a multi-inhibitor of PTK and used to treat renal carcinoma [65]. Oxyindole inhibitors are also known for FGFR1 [66]. At the same time the search for active and selective inhibitors of protein kinases among oxyindoles is in progress [67]. The highest activity towards FGFR1 among the investigated derivatives of oxyindoles was demonstrated by (2-oxo-1,2-dihydroindole3-idine)-hydrazide-2-hydroxybenzoic acid. $\mathrm{IC}_{50}$ for this compound is $1.25 \mu \mathrm{M}$ [57].

The most efficient inhibitors of FGFR1 were revealed among the representatives of quinazolines. High in- hibitory activity towards FGFR1 was demonstrated by compounds of subclass of 4-anilinoquinazolines. Contrary to compounds of other investigated classes, three representatives of 4-anilinoquinazolines (ACH24, $\mathrm{ACH} 25$ and $\mathrm{ACH} 26$ ) inhibit the activity of FGFR1 in submicromolar concentrations [58]. It is noteworthy that the derivatives of quinazolines are capable to inhibit receptor tyrosine kinases EGFR [68] (gefitinib and erlotinib - EGFR inhibitors, used in the clinical practice as anticancer drugs) and VGFR [69].

Inhibitors of protein kinase ASK1. ASK1 (apoptosis signal-regulating kinase 1) is a serine/threonine protein kinase, involved in the control of differentiation, aging, inflammatory processes and apoptosis, depending on the type and redox status of cells as well as on the development of immune response [70,71]. The increased activity of ASK1 is related to various diseases - fibrous histiocytoma [72], gastric cancer [73], Alzheimer's disease [74-76], amyotrophic lateral sclerosis [77], myocarditis, heart fibrosis and other cardiovascular pathologies $[78,79]$. Thus ASK1 inhibitors may be used as drugs for treatment of oncological, neurodegenerative and cardiovascular diseases.

At present there are several communications on the developed inhibitors of protein kinase ASK1. One class of inhibitors of this enzyme is patented [80]. Recently there has been an article of Japanese investigators on the search for ASK1 inhibitors using the virtual screening technology [81], in which the authors managed to find inhibitors only with $\mathrm{IC}_{50}$ in the range of $13-25 \mu \mathrm{M}$.

The technology of rational design was used (Volynets et al.) to develop two new ATP-competitive classes of ASK1 protein kinase inhibitors - on the basis of 2-thioxo-thiazolidine-4-one derivatives and $3 \mathrm{H}$-naphtho[1,2,3-de]quinoline-2,7-dione derivatives [8284]. Both classes were demonstrated to interact with ATP-acceptor site of protein kinase ASK1 via common structural mechanisms. The fixation of compounds in ATP-binding pocket of ASK1 occurs due to hydrophobic interactions of inhibitors and amino acid residues Leu686, Val694, Ala707, Met754, Val757, Val738 and Leu810 as well as because of the formation of hydrogen bonds with the hinge and phosphate-binding site of the enzyme.

Among the representatives of 2-thioxo-thiazolidine-4-ones, the highest activity was demonstrated by 
compound PFTA-1 - 2-\{5-[5-(3,4-dichlorophenyl)-furan-2-ilmethylen]-4-oxo-2-thioxo-thiazolidine-3-yl\}propanoic acid with submicromolar activity towards ASK $1-\mathrm{IC}_{50}$ is $650 \mathrm{nM}$, and $K_{i}-340 \mathrm{nM}$ [83].

The inhibitor selectivity was investigated in the reaction in vitro with protein kinases Aurora A, CK2, JNK3, FGFR1, HGFR1, Tie2 and appropriate substrates for each enzyme. The results demonstrated that the inhibitor is specific to ASK1 except for the inhibitory activity towards protein kinase Aurora A (the residual activity of protein kinase Aurora A after the introduction of $10 \mu \mathrm{M}$ of the inhibitor is $15 \%$ ). Thus, this compound is promising for further optimization [83].

According to the results of structural analysis of the interaction of PFTA-1 and ASK1 in silico and testing in vitro, 5-(5-phenyl-furan-2-ylmethylen)-2-thioxo-thiazolidine-4-one, that is the structural basis for compound PFTA-1, may serve as a pharmacophore for the design of inhibitors of protein kinase ASK1. 32 new derivatives of 5-(5-phenyl-furan-2-ylmethylen)-2-thioxothiazolidine-4-one were synthesized, 17 of them demonstrated inhibitory activity in submicromolar concentrations. The most active ligands inhibit ASK1 with $\mathrm{IC}_{50}=$ $=200-300 \mathrm{nM}[82,83]$.

Among derivatives of $3 \mathrm{H}$-naphtho[1,2,3-de]quinoline-2,7-diones the most active compound is ethyl 2,7dioxo-2,7-dihydro-3H-naphtho[1,2,3-de]quinoline-1carboxylate, called NQDI-1. It inhibits the activity of protein kinase ASK1 with $\mathrm{IC}_{50}=3000$ and $K_{i}=500 \mathrm{nM}$ [84]. The selectivity of inhibitor NQDI-1 was investigated in the reactions in vitro with protein kinases Aurora A, CK2, JNK3, ROCK1, FGFR1, HGFR1, Tie2 and specific substrates for each enzyme. The investigations demonstrated that the inhibitor has specific activity towards ASK1 [84].

\section{С. М. Ярмолюк, О. Ю. Нипорко, В. Г. Бджола}

Раціональний дизайн інгібіторів протеїнкіназ

Резюме

Сучасні методологічні підходи до рачіонального дизайну низькомолекулярних сполук, щзо характеризуються специфічною активністю щьодо заданих біомолекулярних мішеней, розглянуто на прикладі розробки високоефективних інгібіторів протеїнкіназ. Висвітлено нові обчислювальні методи, застосування яких дає змогу суттєво покращити якість комп 'ютерних експериментів (зокрема, точність передбачення активності низькомолекулярних сполук) без збільшення розрахункових потужностей та витрати часу. Ефективність стратегї раціонального дизайну під- тверджено низкою власних досліджень з розробки нових інгібіторів протеїнкіназ CK2, FGFR1 і ASK1.

Ключові слова: раціональний дизайн, інгібітори протеїнкіназ, низькомолекулярні сполуки, протеїнкінази CK2, FGFR1 i ASK1.

\section{С. Н. Ярмолюк, А. Ю. Ныпорко, В. Г. Бджола}

Рациональный дизайн ингибиторов протеинкиназ

Резюме

Современные методологические подходы к рациональному дизайну низкомолекулярных соединений, характеризуюшихся специфической активностью по отношению к заданным биомолекулярным мишеням, рассмотрены на примере разработки высокоэффективных ингибиторов протеинкиназ. Освещены новые вычислительные методы, применение которых дает возможность значительно улучшить качество компьютерных экспериментнов (в частности, точность предсказания активности низкомолекулярных соединений) без увеличения расчетных мощпностей и затрат времени. Эффективность стратегии рационального дизайна подтверждена рядом собственных иссле-дований по созданию новых ингибиторов протеинкиназ CK2, FGFR1 и ASK1.

Ключевые слова: рачиональный дизайн, ингибиторы протеинкиназ, низкомолекулярные соединения, протеинкиназы CK2, FGFR1 u ASK1.

\section{REFERENCES}

1. Manning G., Whyte D. B., Martinez R., Hunter T., Sudarsanam S The protein kinase complement of the human genome // Science.-2002.-298, N 5600.-P. 1912-1934.

2. Johnson L. N., Noble M. E., Owen D. J. Active and inactive protein kinases: structural basis for regulation // Cell.-1996.-85, N 2.-P. 149-158.

3. Huse M., Kuriyan J. The conformational plasticity of protein kinases // Cell.-2002.-109, N 3.-P. 275-282.

4. Nolen B., Taylor S., Ghosh G. Regulation of protein kinases; controlling activity through activation segment conformation // Mol. Cell.-2004.-15, N 5.-P. 661-675.

5. Blume-Jensen P., Hunter T. Oncogenic kinase signalling // Nature.-2001.-411, N 6835.-P. 355-365.

6. Murray N. R., Kalari K. R., Fields A. P. Protein kinase Ci expression and oncogenic signaling mechanisms in cancer // J. Cell. Physiol.-2011.-226, N 4.-P. 879-887.

7. Cohen $P$. Protein kinases - the major drug targets of the twentyfirst century? // Nat. Rev. Drug Discov.-2002.-1, N 4.-P. 309-315.

8. Petrelli A., Giordano S. From single- to multi-target drugs in cancer therapy: when aspecificity becomes an advantage// Curr. Med. Chem.-2008.-15, N 5.-P. 422-432.

9. Backes A. C., Zech B., Felber B., Klebl B., Muller G. Small-molecule inhibitors binding to protein kinases. Part I: exceptions from the traditional pharmacophore approach of type I inhibition // Expert Opin. Drug Discov.-2008.-3, N 12.-P. 1409-1425.

10. Schwartz P. A., Murray B. W. Protein kinase biochemistry and drug discovery // Bioorg. Chem.-2011.-39, N 5-6.-P. 192-210.

11. Eglen R., Reisine T. Drug discovery and the human kinome: recent trends // Pharmacol. Ther.-2011.-130, N 2.-P. 144-156.

12. Yakovenko O., Oliferenko A. A., Bdzhola V. G., Palyulin V. A., Zefirov N. S. Kirchhoff atomic charges fitted to multipole moments: Implementation for a virtual screening system // J. Comput. Chem.-2008.-29, N 8.-P. 1332-1343. 
13. Yakovenko O. Y., Li Y. Y., Oliferenko A. A. et al. Ab initio parameterization of YFF1, a universal force field for drug-design applications // J. Mol. Model.-2012.-18, N 2.-P. 663-673.

14. Yakovenko O. Ya., Oliferenko A. A., Golub G. A., Bdzhla V. G., Yarmolyuk $S$. $M$. The new method of distribution integrals evaluations for high throughput virtual screening // Ukr. Bioorg. Acta.-2007.-5, N 1.-P. 52-62.

15. Oliferenko A. A., Palyulin V. A., Pisarev S. A., Neiman A. V., Zefirov $N$. $S$. Novel point charge models: reliable instruments for molecular electrostatic // J. Phys. Org. Chem.-2001.-14, N 6.- P. 355-369.

16. Halgren T. A. Merck molecular force field. I. Basis, form, scope, parameterization, and performance of MMFF94 // J. Comp. Chem.-1996.-17, N 5-6.-P. 490-519.

17. Ooi T., Oobatake M., Nemethy G., Scheraga H. A. Accessible surface-areas as a measure of the thermodynamic properties of hydration of peptides // Proc. Natl Acad. Sci. USA.-1987.-84, N 10.-P. 3086-3090.

18. Bruccoleri R. E., Novotny J., Davis M. E. Finite difference Poisson-Boltzmann electrostatic calculations: increased accuracy achieved by harmonic dielectric smoothing and charge antialiasing // J. Comput. Chem.-1997.-18, N 2.-P. 268-276.

19. Hawkins G. D., Cramer C. J., Truhlar D. G. Pairwise solute descreening of solute charges from a dielectric medium // Chem. Phys. Lett.-1995.-246, N 1-2.-P. 122-129.

20. Yakovenko O. Ya., Golub A. G., Bdzhola V. G., Yarmoluk S. M. Application of distribution function of rotation and translation degrees of freedom for CK2 inhibitors $\mathrm{K}_{\mathrm{i}}$ estimation // Ukr. Bioorg. Acta.-2006.-4, N 2.-P. 47-55.

21. Dittie A. S., Thomas L., Thomas G., Tooze S. A. Interaction of furin in immature secretory granules from neuroendocrine cells with the AP-1 adaptor complex is modulated by casein kinase II phosphorylation // EMBO J.-1997.-16, N 16.-P. 4859-4870.

22. Mauxion F., Le Borgne R., Munier-Lehmann H., Hoflack B. A casein kinase II phosphorylation site in the cytoplasmic domain of the cation-dependent mannose 6-phosphate receptor determines the high affinity interaction of the AP-1 Golgi assembly proteins with membranes // J. Biol. Chem.-1997.-271, N 4.P. 2171-2178.

23. Sarrouilhe D., Filhol O., Leroy D. et al. The tight association of protein kinase CK2 with plasma membrane is mediated by a specific domain of its regulatory beta-subunit // Biochim. Biophys. Acta.-1998.-1403, N 2.-P. 199-210.

24. Faust M., Montenarh M. Subcellular localization of protein kinase CK2. A key to its function? // Cell Tissue Res.-2000.-301, N 3.-P. 329-340.

25. Meggio F., Pinna L. A. One-thousand-and-one substrates of protein kinaseCK2? // FASEB J.-2003.-17, N 3.-P. 349-368.

26. Ahmad K. A., Wang G., Unger G., Slaton J., Ahmed K. Protein kinase CK2 - a key suppressor of apoptosis // Adv. Enzyme Regul.-2008.-48.-P. 179-187.

27. Filhol $O$., Cochet $C$. Protein kinase $\mathrm{CK} 2$ in health and disease: cellular functions of protein kinase CK2: a dynamic affair // Cell. Mol. Life Sci.-2009.-66, N 11-12.-P. 1830-1839.

28. St-Denis N. A., Litchfield D. W. Protein kinase CK2 in health and disease: from birth to death: the role of protein kinase CK2 in the regulation of cell proliferation and survival // Cell. Mol. Life Sci.-2009.-66, N 11-12.-P. 1817-1829.

29. Daya-Makin M., Sanghera J. S., Morgentale T. L. et al. Activation of a tumor-ssociated protein kinase (p40TAK) and casein kinase 2 in human squamous cell carcinomas and adenocarcinomas of the lung // Cancer Res.-1994.-54, N 8.-P. 22622268

30. Faust R. A., Gapany M., Tristani P. et al. Elevated protein kinase CK2 activity in chromatin of head and neck tumors: associa- tion with malignant transformation // Cancer Lett.-1996.-101, N 1.-P. 31-35.

31. Landesman-Bollag E., Romieu-Mourez R., Song D. H. et al. Protein kinase CK2 in mammary gland tumorigenesis // Oncogene.2001.-20, N 25.-P. 3247-3257.

32. Stalter G., Siemer S., Becht E. et al. Asymmetric expression of protein kinase CK2 subunits in human kidney tumors // Biochem. Biophys. Res. Commun.-1994.-202, N 1.-P. 141-147.

33. Trembley J. H., Wang G., Unger G., Slaton J., Ahmed K. Protein kinase CK2 in health and disease: CK2: a key player in cancer biology // Cell. Mol. Life Sci.-2009.-66, N 11-12.P. 1858-1867.

34. Yenice S., Davis A. T., Goueli S. A. et al. Nuclear casein kinase 2 (CK-2) activity in human normal, benign hyperplastic, and cancerous prostate // Prostate.-1994.-24, N 1-P. 11-16.

35. Raftery M., Campbell R., Glaros E. N., et al. Phosphorylation of apolipoproteinE at an atypical protein kinase CK2 PSD/E site in vitro // Biochemistry.-2005.-44, N 19.-P. 7346-7353.

36. Yamada M., Katsuma S., Adachi T. et al. Inhibition of protein kinase CK2 prevents the progression of glomerulonefritis // Proc. Natl Acad. Sci. USA.-2005.-102, N 21.-P. 7736-7741.

37. Singh N. N., Ramji D. P. Protein kinase CK2, an important regulator of the inflammatory response? // J. Mol. Med. (Berl).-2008.86, N 8.-P. 887-897.

38. Ljubimov A. V., Caballero S., Aoki A. M. et al. Involvement of protein kinase CK2 in angiogenesis and retinal neovascularization // Invest. Ophthalmol. Vis. Sci.-2004.-45, N 12.-P. 4583-4591.

39. Cozza G., Pinna L. A., Moro S. Protein kinase CK2 inhibitors: a patent review // Expert Opin. Ther. Patents-2012.-22, N 9.P. 1081-1097.

40. Pat. UA68984 A, C07D215/00. Application of 4- substituted 3-carboxyquinolines as protein kinase CK2 inhibitors / V. M. Sapelkin, S. S. Lukashov, A. G. Golub, O. Ya. Yakovenko, V. G. Bdzhola, G. G.Dubinina, S. M. Yarmoluk// Publ. 2004-08-16.

41. Golub A. G., Yakovenko O. Y., Bdzhola V. G. et al. Evaluation of 3-carboxy-4(1H)-quinolones as inhibitors of human protein kinase CK2 // J. Med. Chem.-2006.-49, N 22.-P. 6443-6450.

42. Pat. UA69165 A, C07D215/00. Application of 4,5, 6,7-tetrahalogeno-1,3-isoindolinediones as protein kinase CK2 inhibitors / A. O. Prykhod'ko, A. G. Golub, O. Ya. Yakovenko, V. G. Bdzhola, G. G. Dubinina, S. M. Yarmoluk // Publ. 2004-08-16.

43. Golub A. G., Yakovenko O. Y., Prykhod'ko A. O., et al. Evaluation of 4,5,6,7-tetrahalogeno-1H-isoindole-1,3(2H)-diones as inhibitors of human protein kinase CK2 // Biochim. Biophys. Acta.-2008.-1784, N 1.-P. 143-149.

44. Battistutta R., De Moliner E., Sarno S., Zanotti G., Pinna L. A. Structural features underlying selective inhibition of protein kinase CK2 by ATP-site directed tetrabromo-2-benzotriazole // Protein Sci.-2001.-10, N 11.-P. 2200-2206.

45. Sapelkin V. M., Golub A. G., Yakovenko O. Ya., Bdzhola V. G., Yarmoluk S. M. Search for kasein kinase 2 inhibitors among 4 aminoquinazoline derivatives // Ukr. Bioorg. Acta.-2004.-1, N 1-2.-P. $74-79$.

46. Sapelkin V. M., Golub A. G., Yakovenko O. Ya., Bdzhola V. G., Yarmoluk S. M. Search for protein kinase CK2 inhibitors among 3-carboxy-4-aminoquinoline derivatives // Ukr. Bioorg. Acta.2005.-2, N 1.-P. 28-32.

47. Liu X. G., Liang N. C. Inhibitory effect and its kinetic analysis of tyrphostin AG1478 on recombinant human protein kinase CK2 holoenzime // Acta Pharmacol. Sin.-2002.-23, N 6.-P. 556-561.

48. Golub A. G., Bdzhola V. G., Kyshenia Y. V. et al. Structure-based discovery of novel flavonol inhibitors of human protein kinase CK2 // Mol. Cell. Biochem.-2011.-356, N 1-2.-P. 107115. 
49. Golub A. G., Bdzhola V. G., Briukhovetska N. V. et al. Synthesis and biological evaluation of substituted (thieno[2,3-d]pyrimidin-4-ylthio)carboxylic acids as inhibitors of human protein kinase CK2 // Eur. J. Med. Chem.-2011.-46, N 3.-P. 870-876.

50. Munchhof M. J., Beebe J. S., Casavant J. M. et al. Design and SAR of thienopyrimidine and thienopyridine inhibitors of VEGFR-2 kinase activity // Bioorg. Med. Chem. Lett.-2004.-14, N 1.P. 21-24.

51. Dai Y., Guo Y., Frey R. R. et al. Thienopyrimidine ureas as novel and potent multitargeted receptor tyrosine kinase inhibitors // J. Med. Chem.-2005.-48, N 19.-P. 6066-6083.

52. Woods E. R., Shewchuk L. M., Ellis B. et. al. 6-Ethynylthieno[3, 2-d]-and 6-ethynylthieno[2,3-d]pyrimidin-4-anilines as tunable covalent modifiers of ErbB kinases // Proc. Natl Acad. Sci. USA.2008.-105, N 8.-P. 2773-2778.

53. Hughes $S$. E. Differential expression of the fibroblast growth factor receptor (FGFR) multigene family in normal human adult tissues // J. Histochem.. Cytochem.-1997.-45, N 7.-P. 1005-1019.

54. Wesche J., Haglund K., Haugsten E. M. Fibroblast growth factors and their receptors in cancer // Biochem. J.-2011.-437, N 2.P. 199-213.

55. Greulich H., Pollock P. M. Targeting mutant fibroblast growth factor receptors in cancer // Trends Mol Med.-2011.-17, N 5.P. 283-292.

56. Grischenko A. A., Bdzhola V. G., Kukharenko O. P., Yarmoluk $S$. M. Search for FGFR1 inhibitors among chromone derivatives // Ukr. Bioorg. Acta.-2009.-7, N 1.-P. 50-56

57. Grischenko A. A., Bdzhola V. G., Borovikov O. V. et al. Search for FGFR1 inhibitors among oxindole derivatives // Ukr. Bioorg. Acta.-2009.-7, N 2.-P. 64-68.

58.Gryshchenko A. A., Bdzhola V. G., Lukashov S. S. et al. Quinazoline inhibitors of protein kinase FGFR1 // Ukr. Bioorg.Acta.2010.-8, N 2.-P. 63-68.

59. Fischer P. M., Gianella-Borradori A. Recent progress in the discovery and development of cyclin-dependent kinase inhibitors // Expert Opin. Investig. Drugs.-2005.-14, N 4.-P. 457-477.

60. Sarno S., Moro S., Meggio F. et al. Toward the rational design of protein kinase casein kinase-2 inhibitors // Pharmacol. Ther.2002.-93, N 2-3.-P. 159-168.

61. Fotsis T., Pepper M. S., Aktas E. et al. Flavonoids, dietary-derived inhibitors of cell proliferation and in vitro angiogenesis // Cancer Res.-1997.-57, N 14.-P. 2916-2921.

62. Lu H. S., Chang D. J., Baratte B., Meijer L., Schulze-Gahmen U. Crystal structure of a human cyclin dependent kinase 6 complex with a flavonol inhibitor, fisetin // J. Med. Chem.-2005.-48, N 3.-P. 737-743.

63. Holder S., Zemskova M., Zhang C. et al. Characterization of a potent and selective small molecule inhibitor of the PIM1 kinase // Mol. Cancer Ther.-2007.-6, N 1.-P. 163-172.

64. Walker E. H., Pacold M. E., Perisic O. et al. Structural determinants of phosphoinositide 3-kinase inhibition by wortmannin, LY294002, quercetin, myricetin, and staurosporine // Mol. Cell.2000-6, N 4.-P. 909-919.

65. Prakash C. R., Theivendren P., Raja S. Indolin-2-ones in clinical trials as potential kinase inhibitors: a review // Pharmacol. Pharm.-2012.-3, N 1.-P. 62-71.

66. Mohammadi M., McMahon G., Sun L. et al. Structures of the tyrosine kinase domain of fibroblast growth factor receptor in complex with inhibitors // Science.-1997.-276, N 5314.P. 955-960.

67. Kim M. H., Tsuhako A. L., Co E. W. et al. The design, synthesis, and biological evaluation of potent receptor tyrosine kinase inhibitors // Bioorg. Med. Chem. Lett.-2012.-22, N 15.-P. 4979 4985.

68. Rewcastle G. W., Denny W. A., Bridges A. J. et al. Tyrosine kinase inhibitors. 5. Synthesis and structure-activity relationships for 4-[(phenylmethyl)amino]- and 4-(phenylamino)quinazolines as potent adenosine 5'-triphosphate binding site inhibitors of the tyrosine kinase domain of the epidermal growth factor receptor // J. Med. Chem.-1995.-38, N 18.-P. 3482-3487.

69. Hennequin L. F., Thomas A. P., Johnstone C. et al. Design and structure-activity relationship of a new class of potent VEGF receptor tyrosine kinase inhibitors // J. Med. Chem.-1999.-42, N 26.-P. 5369-5389.

70. Matsuzawa A., Saegusa K., Noguchi T. et al. ROS-dependent activation of the TRAF6-ASK1-p38 pathway is selectivity required for TLR4-mediated innate immunity // Nat. Immunol.2005.-6, N 6.-P. 587-592.

71. Noh K. T., Park Y. M., Cho S. G., Choi E. J. GSK-3ß-induced ASK1 stabilization is crucial in LPS-induced endotoxin shock // Exp. Cell. Res.-2011.-317, N 12.-P. 1663-1668.

72. Chibon F., Mariani O., Derre J. et al. ASK1 (MAP3K5) as a potential therapeutic target in malignant fibrous histiocytomas with 12q14-q15 and 6q23 amplifications // Genes Chromosomes Cancer.-2004.-40, N 1.-P. 32-37.

73. Hayakawa Y., Hirata Y., Nakagawa H. et al. Apoptosis signalregulating kinase 1 and cyclin D1 compose a positive feedbach loop contributing to tumor growth in gastric cancer // Proc. Natl Acad. Sci. USA.-2011.-108, N 2.-P. 780-785.

74. Hashimoto Y., Niikura T., Chiba T. et al. The cytoplasmic domain of Alzheimer's amyloid-beta protein precursor causes sustained apoptosis signal-regulating kinase 1/c-Jun NH2-terminal kinase-mediated neurotoxic signal via dimerization // J. Pharmacol. Exp. Ther.-2003.-306, N 3.-P. 889-902.

75. Liu J., Li C., Xing G. et al. Beta-asarone attenuates neuronal apoptosis induced by Beta amyloid in rat hippocampus // Yakugaku Zasshi.-2010.-130, N 5.-P. 737-746.

76. Tachi N., Hashimoto Y., Matsuoka M. MOCA is an integrator of the neuronal death signals that are activated by familial Alzheimer's disease-related mutants of amyloid $\beta$ precursor protein and presenilins // Biochem J.-2012.-442, N 2.-P. 413-422.

77. Nishitoh H., Kadowaki H., Nagai A. et al. ALS-linked mutant SOD1 induces ER stress- and ASK1-dependent motor neuron death by targeting Derlin-1// Genes Dev.-2008.-22, N 11.P. 1451-1464.

78. Hikoso S., Ikeda Y., Yamaguchi O. et al. Progression of heart failure was suppressed by inhibition of apoptosis signal-regulating kinase 1 via transcoronary gene transfer // J. Am. Coll. Cardiol.2007.-50, N 5.-P. 453-462.

79. Yamamoto E., Dong Y. F., Kataoka K. et al. Olmesartan prevents cardiovascular injury and hepatic steatosis in obesity and diabetes, accompanied by apoptosis signal regulating kinase-1 inhibition // Hypertension.-2008.-52, N 3.-P. 573-580.

80. Pat. USA WO 2008016131 A1. Fused heterocyclic compound/ N. Sakai, H. Suzuki, Y. Terao, O. Uchikawa // PCT/JP2007/ 065227; Publ. 7 February 2008.

81. Okamoto M., Saito N., Kojima H. et al. Identification of novel ASK1 inhibitors using virtual screening // Bioorg. Med. Chem.2011.-19, N 1.-P. 486-489.

82. Volynets G. P., Bdzhola V. G., Kukharenko O. P., YarmolukS. M. Identification of low-molecular inhibitors of proteinase ASK1 // Ukr. Biokhim Zh.-2010.-82, N 5.-P. 41-50.

83. Volynets G. P., Bdzhola V. G., Golub A. G. et al. Rational design of apoptosis signal-regulating kinase 1 inhibitors: discovering novel structural scaffold // Eur. J. Med. Chem.-2013.-61.P. 104-115.

84. Volynets G. P., Chekanov M. O., Synyugin A. R. et al. Identification of 3H-naphtho[1,2,3-de]quinoline-2,7-diones as inhibitors of apoptosis signal-regulating kinase 1 (ASK1) // J. Med. Chem.2011.-54, N 8.-P. 2680-2686. 